\title{
Motivation, Work Stress and Job Performance: An Analytical Study of Faculty in Higher Education Institutions of Sindh
}

\author{
Zahida Abro ${ }^{1}$ \\ Muhammad Abdus Salam²
}

\begin{abstract}
Human Resources are very important for the organizations in the current competitive business environment and Human capital's well-being is one of the strong components to achieve organizational performance; this well-being is only possible when there is a low level of stress \& high level of motivation maintained in working environment. Motivation of employees play a dual role, one it increases positive work-related outcomes second, it reduces level of stress, since motivated workforce conserve a healthy, competitive and congenial environment. Thus, the study aimed to explore the hidden relationship of job stress, motivation and job performance in Higher Educational Institutions operating in Sindh, Pakistan. This research is deductive in nature, with empirical approach and has been conducted through cross sectional survey by using structured tool to collect quantitative data. A sample of 155 faculty members working in higher educational universities in Sindh Province has been selected on convenience sampling basis from three public universities. The data analysis and findings provides insights and we may conclude that overall faculty working in public universities operating in Sindh report less stress level in context of teaching, but they do take stress for research and administrative activities. Their job performance is not affected by the stress level at workplace. Moreover, the relationship between motivation and stress has been found negative, job stress and motivation factors are found significant to the performance of the faculty.
\end{abstract}

Keywords: Job stress, Motivation, Job Performance, HEI (Higher Education Institutes)

\section{Introduction}

Human resources are very important for the organizations in the current competitive business environment (Boselie \& Wiele, 2002) considered life line for organizations' survival. Further, well-being of human capital is one of the strong components to achieve organizational performance (Kotteler \& Keller, 2006) and this well-being is only possible when there is a low level of stress \& high level of motivation practiced in work environment. Motivation is a psychological process that shapes a particular behavior; highly motivated employees not only perform well but can control job stress which is usually experienced at work place (Kreitner, 1995).

The term stress has been taken from physical science which means pressure applied over an object to maintain its actual position. Different schools of thoughts have different meanings of stress; for an example one group suggested that stress is stimulus phenomenon, when others elaborated an outcome of stimulus and body response to mental and physical reaction

\footnotetext{
${ }^{1}$ Zahida Abro is Assistant Professor, Management Sciences, SZABIST, Larkana, abroo@lrk.szabist.edu.pk

${ }^{2}$ Muhammad Abdus Salam is Deputy Director, Statistics \& DW Department, State Bank of Pakistan, Karachi, muhammad.abudussalam@sbp.org.pk
}

\begin{tabular}{llll|l}
\hline JISR-MSSE & Volume 12 & Number 2 & July-December 2014 & 17
\end{tabular}


generated through internal/external pressures. Stress has generally been defined Rees (1997) as a state of mind where pressure of job could not be sustained by employees at work place. In organizational context the term has gained popularity among researchers as "occupational stress", especially in corporate world but still a dearth of research has been found in Academia in relation to faculty stress (Aqsa \& Akhtar, 2011). Employees experience stress when they are unable to control work demands (Lesage \& Berjot, 2011). In any work context, normally management put pressure upon employees to achieve targeted goals but the level of pressure has never been defined in management theories and practices. Moreover, stress as pressure is not a negative word as it is commonly considered; pressure at times is desirable to have efficient and effective work outcomes. Therefore, in order to achieve high performance, a reasonable level of stress is essential (Takahashi, 2014).

Motivation is an internal force, a willingness to work at our own without any pushing force. The dimensions of the motivation theories are based upon certain human needs for an example basic needs, psychological needs, safety, career growth, relatedness, fairness at work and so forth and needs are to be satisfied for effective employees' performance (Stein et al., 1992). There are number of job motivators like work itself, acknowledgment, career growth, money, social status, authority, respect, flexible time, role clarity, retirement benefits and responsibility. Apart from these factors employees' related policies, good working atmosphere, boss relationship, positive terms with sub ordinates, career growth, provision of basic facilities, overtime opportunities etc. are also considered motivational factors (Singh, 2007). Motivation plays a vital role to enhance performance and is significantly related to other positive work outcomes like, low absenteeism, less turnover, OCB, high retention. Highly motivated employees have ability to control stress and maintain work balance under pressure.

Teachers are considered pillars of educational institutes; they are mainly responsible to build nations by providing knowledge and wisdom to the young generation. No one can dream schools, colleges and universities without teaching faculty. Generally, in all professions and specifically in teaching profession peace of mind at work place is essential element to give the best of one's working potential, abilities and capabilities. Although, it is generally considered that teaching profession is not that stressful as compared to other professions (French et al., 2002) but now a days faculty workload has been increasing in terms of teaching learning and research activities, also working environment has been found less supportive in relation to ideal job dimensions, autonomy, freedom of voice, decision making, career growth and so forth, which results in high level of job stress among teaching staff (Erkutla \& Chafra, 2006) which leads faculty towards dissatisfaction and decreases professional dedication (Singh, 2007).

As higher education has undergone tremendous changes since last two decades which put more pressure on faculty and created stress, results low motivation and reduce work performance. Thus, this study aims to investigate the linkage between the job stress, motivation, and job performance of faculty working in higher education institutions of Sindh. The objectives of the study are to identify the motivation, stress, and performance level of faculty members of HEI in Sindh and to examine the effect these factors on performance with moderating effect of demographic factors.

The study provides insights to the management of higher educational institutes to develop strategies and adopt constructive practices to enhance employees performance through job 
motivation, controlled stress level to achieve the optimal level of job performance; which ultimately shall have a positive impact upon universities overall performance. The study will cover three public universities of Sindh Province providing higher education. The criterion of selecting these public universities is based on the convenience and willingness of the faculty to participate in the survey. Moreover, permanent faculty works in public universities have minimum one year experience will be approached.

\section{Literature Review}

Job stress is a pressure of undesirable conditions at work place (Montgomery et al., 1996). This is also supported by Quick et al. (1997) work stress is psychological construct, employees in one way or another experience work stress on daily basis. People in any job environment come across with unachievable job demands (Gmelch, 1982) that creates stress due to high level of variation between work demand and working ability, and in extreme cases stress turns into burnout; a state of severe stress that may increases risk of life lead people to mortality (Lu et al., 2003).

Researchers around the world have strong consensus in relation to variables associated with job stress such as time pressure, poor working conditions, over work load, role of employees, career growth, job security, politics, lack of empowerment, low morale, loss of productivity, high turnover, poor interpersonal relations, self leaves, conflicts at work place, stretched customers' relations etc. External environment factors also contribute to job stress like social problems, family problems \& self- problems (Lu et al., 2003). In this relation to job stressors, Erkutla \& Chafra (2006) also pointed out a few factors initiating stress like job itself, organizational structure, role related issues, peer relationship, and career growth.

Faculty stress underlies negative emotions associated with unpleasant experiences at work place. Teaching faculty due to the high demand for research and learning activities at higher educational level, Kyricon (2001) requires time and efforts for scholarly work/ Research, publications apart from teaching, that put heavy burden results high work pressure which ultimately put them under stress, (Takashi, 2014). Nevertheless, academic stress could be controlled by demographic factors like age, education, status, gender, income apart from organizational components like motivation and congenial environment at work place. Makumbo (2014) Demographic variables create variance in respondents' opinion; female faculty takes more stress as compared to male faculty members. Carr (2014) also examined stress to tenure; he reported higher occupational stress amongst newly inducted faculty as compared to senior faculty.

This is also reported earlier by Elizabeth (1986) as she described in stress related study that age, work set up, rank and gender influences level of stress. In her study she pointed out three major factors associated with stress; namely teaching, research \& institutional task, in all these factors time and task were taken as major parts of subscales.

In connection with Academic research, Makumbo (2014) pointed out workload causes greater stress among faculty members as compared to job control, organizational support, role itself and job demands. Furthermore, Aqsa and Akbar (2011) found workload, students' issues and role conflicts are more influencing factors associated with faculty stress. On the contrary, Takashi (2014) pointed out that faculty do not take much stress for research work as compared 
to teaching and administrative work. The author also elaborated stress as a major cause of different physiological, mental, and work related problems, employees living with constant psychological stress may experience headaches, back pain and loss of appetite. Meller et al., (2005) added that stress creates; hypertension, heart problems, suffocation, asthma, migraine, alcoholism, sexual dysfunction, peptic ulcers and very severe suicide are stress related issues.

These stress related problems are accountable for major organizational cost due to low job performance, high turnover, trainings, absenteeism, low employees moral, less productivity, lack of trust, low concentration, easily getting tired, and dissatisfaction (Dyck, 2001). Therefore, stress may be considered as a negative factor in relation to positive work outcomes because it influences behavioral disturbance and affects employees' performance (Willy, 2000).

However, some researchers take stress as positive factor that may enhance work performance, Farooq (2003) elaborated that an optimal level performance requires moderate level of stress, this results high productivity. This may underlies a concept that stress is not negative as people think generally based upon the literally meaning of the word but it has a positive implication upon job performance in certain cases.

Motivation the second component of this study is very important aspect of human behavior and has been extensively studied in educational and other research context, Barkoukis et al. (2008). Motivation as a concept is an internal force pushing to do anything without any external force. Theoretically, high motivated employees are more willing to coup up with stress level compared to low motivated employees. Thus, motivation is considered as an active force which reduces job stress but the relationship between motivation and job stress in certain studies has been found negative. Jamal (1990) found in one of his study based upon job stress and motivation a case study full-time hospital nurses that job stress was a key factor reducing or increasing work motivation to stay or to leave the job. Motivation is backed by various factors (e.g. financial rewards, promotions, job status, career growth, moral satisfaction, and self- esteem) and is connected with job performance (Murphy et al., 1999). Motivation leads employees towards satisfaction which increases job performance in the work context. Highly motivated employees are more productive and efficient whereas low motivated employees are burden upon the organization's financial resources and productivity.

There are number of models developed in relation to motivation of employees for an example Alderfer (1967) ERG Model in which the author has elaborated that fulfillment of certain needs is very important in order to improve job performance. ERG model factors (existence, relatedness \& growth) are considered a concise form of Maslow's hierarchy of needs. Hakman and Oldham (1975) also linked autonomy, task variety, feed-back, job significance, and skill variety in their JCM model to enhance employees' motivation. There are number of other models as well which are applies in empirical researches to measure motivation. In this study Aldefer's (ERG) model with existence, relatedness and growth subscales has been used. Theoretical model carries Job stress and Motivation as independent variables, demographic variables as moderators and performance as dependent variables. 


\section{Research Methodology}

This is a descriptive and explanatory research by focusing demographic element; a deductive approach has been used to find out empirical evidences. The research has been conducted through cross sectional survey by using structured tool to collect quantitative data. All permanent faculty members of public universities estimated 2000 teaching in higher education institutions operating in Sindh province has been taken as population of this study. The population has been estimated by using HEC website for all public universities operating in Sindh, then with the help of given websites of the universities, faculty has been listed in numbers. Moreover, visiting or contract faculty have not been taken into account keeping in view their temporary nature of job status. A sample of 200 with $5 \%$ margin of error of whole population has been taken from public universities.

Primary data has been collected through a standard tool based upon three scales motivation, job Stress \& job performance. A Structured questionnaire (a multidimensional scale) developed by taking different scales from research studies; motivation scale is based upon Alderfer's motivation theory, stress scale has been taken from a study "Stress in Academe" developed and used by Elizabeth (1996) and job performance scale borrowed from "Adaptive performance" by Patrice Roussel (1997). These all scales have been merged and gone through pilot testing phase. Under pilot testing initially, 40 questionnaires were released to check the reliability of the tool which has been found satisfactory as per benchmark.

\section{Hypotheses}

$\mathrm{H}_{1}$ : There is no relationship between motivation and job stress

$\mathrm{H}_{2} \mathrm{a}$ : There is no relationship between motivation and performance

$\mathrm{H}_{2}$ b: There is no relationship between job stress and perceived performance

$\mathrm{H} 3 \mathrm{a}$ : Motivation has a positive effect on perceived performance

$\mathrm{H} 3 \mathrm{~b}$ : Job stress has negative effect on perceived performance

$\mathrm{H} 4$ : There is no difference in terms of gender on the relationship among motivation, job stress, and perceived performance

\section{Data Analysis And Discussions}

The major analysis is based on descriptive analysis, correlation and simple regression. The reliability of the analysis is determined by using Cronbach Alpha. Reliability of the whole scale and of individual factors is determined for comparison purpose. The bench mark of Cronbach Alpha is used as 0.6 (as proposed by many researches mentioned in literature review chapter).

Overall, reliability analysis measured by using SPSS 18.0.Cronbanch Alpha value is .799 for 155 cases and five variables containing 40 scale questions, shows data is highly reliable. However, individual reliability of all five variables varies; motivation (IV) has been found high reliability (.824) as compared to Job stress factors (teaching, research \& administration). Apart from this, reliability for dependent variable job performance (.668) is near to the 
benchmark. Research variable which is the component of sub scale of job stress (IV) has found lowest (.53) value even less than the benchmark. Majority of the teaching faculty $(67.1 \%)$ of the total sample in public universities is male dominated as compared to Female faculty $(32.9 \%)$ which indicates that opinion of male faculty will be more dominated over other group of teaching faculty.

Faculty Members (51\%) have Masters Degrees. Next to this category is M.Phil. (34.2\%) and rest of the total sample are PhDs. This indicates that opinion of Masters level group is more influential upon study results. This may lead us towards another insight of the study that job stress among faculty due to research, and administrative activities may come low because faculty at Masters Level is less exposed to research and administrative work as compared to $\mathrm{MS} / \mathrm{PhDs}$.

Table 1

Teachers Perception

\begin{tabular}{lrrrrr}
\hline & Range & Minimum & Maximum & Mean & Std. Deviation \\
\hline Teaching & 3.33 & 1.00 & 4.33 & 2.8323 & .74523 \\
\hline Research & 3.33 & 1.67 & 5.00 & 3.1774 & .59963 \\
\hline Administration & 3.12 & 1.75 & 4.88 & 3.2903 & .69916 \\
\hline Motivation & 3.50 & 1.50 & 5.00 & 3.6877 & .64126 \\
\hline Performance & 2.90 & 2.10 & 5.00 & 3.7277 & .46045 \\
\hline
\end{tabular}

The descriptive analysis of the respondents reveals that overall perception of the teachers for job stress motivation and job performance falls at agreed side for all independent and dependent variables that is more than 3.0 of 1 to 5 scale, where $1=\mathrm{SD}$ and $5=\mathrm{SA}$. Teaching factor which is the component of stress variable has been found at bit disagree side with mean value of 2.8 on the scale that shows faculty is not experiencing stress for teaching activity, which is considered a core activity in teaching field. This shows that teachers fell stress when it comes to research and administrative work, they reported their motivation level positive on scale which means that stress has no link with motivation and does not reduces their performance because mean values of perceived performance are also greater than 3 rather near to four; which means their reported performance goes to agree side on the five point likert scale. Overall standard deviation has found less than 1.0, which shows that there is less variance in the respondent's response.

Table 2

Teachers Perception

\begin{tabular}{lrrrrr}
\hline & Teaching & Research & Administration & Motivation & Performance \\
\hline Teaching & 1 & $.486^{* *}$ & $.551^{* *}$ & $-.158^{*}$ & .100 \\
\hline Research & 1 & $.473^{* *}$ & -.156 & $.239^{* *}$ \\
\hline Administration & & 1 & $-.216^{* *}$ & $.314^{* *}$ \\
\hline Motivation & & & 1 & $.256^{* *}$ \\
\hline Performance & & & & 1 \\
\hline
\end{tabular}

**. Correlation is significant at the 0.01 level (2-tailed).

*. Correlation is significant at the 0.05 level (2-tailed).

\begin{tabular}{l|llll}
\hline 22 & July-December 2014 & Volume 12 & Number 2 & JISR-MSSE
\end{tabular}


The data of all 155 respondents shows that all variables are not significant at 0.01 level of significance. The highest correlation is found between teaching and administration (i.e. .551), next to it is teaching and research (i.e. .486) followed by research and administration (i.e. .473). Negative correlation has been found between stress and motivation which shows stress increases motivation decreases; least correlation (i.e. -.156) is found between research (a component of stress) and motivation. The correlation data shows that the strong correlation has been found among job stress internal subscale variables (teaching, research and administrative duties). On the other hand dependent variable job performance has found significant correlation with all variables at 0.01 significant levels, except one subscale variable teaching. This shows those respondents are of the opinion that teaching is not significantly related with job performance.

\subsection{Impact of Faculty Perception}

\begin{tabular}{lcccc}
\hline Model & $\mathrm{R}$ & R Square & $\begin{array}{c}\text { Adjusted } \mathrm{R} \\
\text { Square }\end{array}$ & $\begin{array}{c}\text { Std. Error of } \\
\text { the Estimate }\end{array}$ \\
\hline 1 & $.413 \mathrm{a}$ & .170 & .159 & .42218 \\
\hline
\end{tabular}

Predictors: (Constant), Job stress, motivation

\begin{tabular}{lrrlrr}
\hline \multicolumn{7}{c}{ Unstandardized Coefficients } & \multicolumn{2}{l}{$\begin{array}{l}\text { Standardized } \\
\text { Coefficients }\end{array}$} \\
\hline Model & $\mathrm{B}$ & Std. Error & Beta & $\mathrm{t}$ & Sig. \\
\hline (Constant) & 2.014 & .309 & & 6.520 & .000 \\
\hline Motivation & .235 & .054 & .328 & 4.329 & .000 \\
\hline Job Stress & .273 & .062 & .331 & 4.379 & .000 \\
\hline
\end{tabular}

Dependent Variable: Performance

\begin{tabular}{lcccc}
\hline Model & $\mathrm{R}$ & R Square & $\begin{array}{c}\text { Adjusted R } \\
\text { Square }\end{array}$ & $\begin{array}{c}\text { Std. Error of } \\
\text { the Estimate }\end{array}$ \\
\hline Male & $.454 \mathrm{a}$ & .206 & .191 & .38988 \\
\hline Female & $.469 \mathrm{a}$ & .220 & .187 & .45842 \\
\hline
\end{tabular}

Dependent variable, performance is explained by independent variables job stress and Motivation by $17 \%$. Hence, Job Performance depends on some other factors which are not considered in this study. This shows that the model is not a good fit model. All factors are significant the contribution of both independent factors; motivation and job stress are almost equal towards dependent variable. The dependent variable job performance is explained by independent variables on average $24 \%$, and there might be other variables which are influencing faculty performance in higher educational public universities operating in Sind. Regression File Split layered by gender shows bit improved R square for female and male as well. Combined regression line showed $17 \%$ dependent variable explained by independent variables but in split file case $22 \%$ line fit goes to female response and $20 \%$ to male faculty response. This indicates that contribution of independent variables has slight different when calculated upon gender based criteria. 


\subsection{Coefficient}

\begin{tabular}{lrrlrl}
\hline \multicolumn{7}{c}{ Unstandardized Coefficients } & \multicolumn{2}{l}{$\begin{array}{l}\text { Standardized } \\
\text { Coefficients }\end{array}$} \\
\hline Model & $\mathrm{B}$ & Std. Error & \multicolumn{1}{l}{ Beta } & $\mathrm{t}$ & Sig. \\
\hline MALE (Constant) & 2.041 & .340 & & 6.010 & .000 \\
\hline Motivation & .295 & .061 & .433 & 4.802 & .000 \\
\hline Job Stress & .181 & .069 & .237 & 2.629 & .010 \\
\hline FEMALE Constant & 1.793 & .621 & & 2.890 & .006 \\
\hline Motivation & .151 & .104 & .192 & 1.451 & .153 \\
\hline Job Stress & .459 & .126 & .482 & 3.644 & .001 \\
\hline
\end{tabular}

Dependent Variable: Performance

Split Regression file upon gender shows that all factors are significant based upon male respondents response. Job Stress has been found significant in female opinion. However, motivation has found insignificant. This means that in female opinion motivation is not contributing more towards job performance.

Key findings of the study are:

- Majority of the teaching faculty $(67.1 \%)$ of the total sample in public universities is male dominated as compared to Female faculty $(32.9 \%)$.

- Majority of faculty Members (51\%) have Masters Degrees. Next to this category is M.Phil. (34.2\%) and rest of the total sample are PhDs.

- Descriptive analysis of the respondents reveals that overall perception of the teachers for job stress motivation and job performance falls at agreed side for all independent and dependent variables that is more than 3.0 of 1 to 5 , where $1=\mathrm{SD}$ and $5=\mathrm{SA}$.

- Descriptive analysis shows that respondents are not taking stress in teaching whereas; for research and administrative duties they reported at agreed side which means they take stress for these two components.

- The data of all 155 respondents shows that all variables are not significantly correlated at 0.01 level of significance. The highest correlation is found between teaching and administration (i.e. .551), next to it is teaching and research (i.e. .486) followed by research and administration (i.e. .473). Whereas, least correlation (i.e. -.156) is found between research and motivation.

- The correlation data shows that the strong correlation has been found among job stress internal subscale variables (teaching, research and administrative duties). On the other hand dependent variable job performance has found significant correlation with all variables at 0.01 significant levels, except one subscale variable teaching.

- Regression analysis shows dependent variable, Performance is explained by independent variables job stress and Motivation by $17 \%$. Hence, Job Performance depends on some other factors that are not considered in this study. This model fit is not considered good. 
- Coefficients in Regression analysis shows All factors are significant because t value is more than two, the contribution of both independent factors; Motivation and Job Stress is almost equal towards dependent variable.

- Split Regression file upon gender shows that all factors are significant based upon male respondents response. Job Stress has been found significant in female opinion. However, motivation has found insignificant.

- Regression File Split layered by gender shows bit improved R square for female and male as well. Combined regression line showed $17 \%$ dependent variable explained by independent variables but in split file case $22 \%$ line fit goes to female response and $20 \%$ to male faculty response.

- Split Regression file upon gender shows that all factors are significant based upon male respondents response. Job Stress has been found significant in female opinion. However, motivation has found insignificant.

\section{Conclusion and Recommendations}

The data analysis and findings provides insight and we can conclude that overall perception of the teaching faculty pertaining to job stress, motivation, and job performance is mixed. The respondents are not taking stress for teaching as a core job responsibility but reported agreement at stress part for research and administrative duties and in their opinion job stress and motivation has negative relationship which shows reciprocal pattern. Faculty generally agreed that there is a correlation between motivation and job performance but for stress to performance they are almost neutral. Moreover, in faculty opinion job stress and motivation is not contributing much to the job performance; there are other factors which may explain job performance in public higher education universities context.

Majority of the faculty has been found in public universities operating in Sindh are male dominated; generally have Master level of education. Male and female opinion about job stress, motivation and job performance varies. In male faculty opinion job stress, motivation contributes towards job performance but on the contrary female faculty perceived that motivation is not contributing in job performance.

Overall faculty in public universities operating in Sindh has less stress level in context of teaching, but research and administrative activities they do fell stressful but their job performance is not affected by the stress level. Further, Motivation level of the faculty is not related with the level of work stress at workplace.

\section{References}

Alderfer, C. P. (1969). Convergent and Discriminant Validation of Satisfaction and Desire Measures by Interviews and Questionnaires, Journal of Applied Psychology, 51(6), 509-20.

Alderfer, C. P. (1969). An Empirical Test of a New Theory of Human Needs', Organizational Behaviour and Human Performance, 4, 142-75. 
Allen, D. R., Hitt, M., Greer, C. R. (1982). Occupational stress and perceived organizational effectiveness in formal groups: an examination of stress level and stress type, Personnel Psychology, 35(2), 359-371.

Aisenberg, N., \& Harrington, M. (1988). Women of Academe: Outsiders in the sacred grove. Amherst University of Massachusetts Press.

Aqsa, A., \& Waheed, A. (2011). Faculty stress at higher education: A study on the Business Schools of Pakistan, World Academy of Science Engineering and Technology.

Blix, A., \& Lee (1991). Occupational stress among university administrators', Research in Higher Education, 32 (3), 289-302.

Boselie, P. \& Wiele, T. (2002). Employee perceptions of HRM and TQM, and the effects on the satisfaction and intention to leave, Managing Service Quality, 12(3), 165-172.

Brown, R. D., Bond, S., Gemdt, J., Krager, L., Krantz, B., Lukin, M., \& Prentice, D. (1986). Stress on campus: An interactional perspective', Research in Higher Education, 24(1), 97-112.

Carr, A. R. (2014). Stress Levels in Tenure-Track and Recently Tenured Faculty Members in Selected Institutions of Higher Education in Northeast Tennessee Electronic Theses and Dissertations.

Chusmir, L. H., \& Franks, V. (1988), Stress and the Woman Manager, Training \& Development Journal, 42(10), 66-70.

Comish, R., Swindle, B. (1994), Managing stress in the workplace, National Public Accountant, 39(9), 24-28.

Cox, T. et al. (1993). Work employment and mental health in Europe, Work and Stress, 18(2). 197-85

Erkutlu, H. V., Chafra, J. (2006). Relationship between leadership power base and job stress of subordinates: example from boutique hotels, Management Research News, 29(5), 285-297.

French, J. R. P., \& Caplan, R. D. (1972). Organizational stress and individual strain. In failure of successeds A J Marrow (Ed.), The. New York: Amacom.

Farooq, A.S. ( 2003). Role of stress in Indian industry: A study of banking organizations, Indian Journal of Industrial Relations, 38(3).

Gummesson, E. (1991). Marketing-orientation revisited: the crucial role of the part-time marketer, European Journal of Marketing, 25(2), 60-75.

Ivancevitch, J. M., \& Matteson, M. (1980). Stress and work: A managerial perspective, Glenview, 11 Scott, Foresman \& Co.

\begin{tabular}{l|llll}
\hline 26 & July-December 2014 & Volume 12 & Number 2 & JISR-MSSE
\end{tabular}


Jamal, M., \& Baba, V. (1992). Shiftwork and department-type related to job stress, work attitudes and behavioral intentions: A study of nurses, Journal of Organizational Behavior, 13, 449-464.

Kotabe, M. \& Helsen, K. (2001). Global Marketing Management, John Wiley and Sons Inc. (2nd ed), US.

Kovach, K. A. (1987). What motivates employees? Workers and supervisors give different answers, Business Horizons, 30(5), 58-65.

Kotler, P. \& Keller, K. L. (2006). Marketing Management, Pearson-Prentice Hall Inc., (12th ed), US.

Kyriacou, C. (2001). Teacher stress: Directions for future research. Educational Research, 53(1), 27-35.

Lease, S. H. (1999). Occupational role stressors, coping, support, and hardiness as predictors of strain in academic faculty: an emphasis on new and female faculty. Research in Higher Education, 40(3), 285-307.

Lu, L, Cooper, C. L., Kao, S-F, Zhou, Y. (2003). Work stress, control beliefs and well-being in Greater China - An exploration of sub-cultural differences between the PRC and Taiwan, Journal of Managerial Psychology, 18(6), 479-510.

Murphy, G. C., \& Athanasou, J. A. (1999). The effect of unemployment on mental health', Journal of Occupational \& Organizational Psychology, 72, 83-99.

Matteson, M. T. \& Ivancevich, J. M. (1987). Work Stress: Effective Human Resource and Management Strategies, Jossey Bass, San Francisco, CA.

Patterson, M. G., West, M. A, Lawthom, R., \& Nickell, S. (1997), Issues in People Management: Impact of People Management Practices on Business Performance, Institute of Personnel and Development (IPD).

Paker, D. F. \& DeCotiis, T. A. (1983). Organisational Determinants of Job Stress, Organisational Behaviour and Human Performance, 24, 160-177.

Quick, J. C., Quick, J.D., Nelson, D.L. \& Hurrell, J. J. (1997). Preventive Stress Management in Organizations', American Psychological Association, Washington, DC.

Rees, W. D. (1997). Managerial stress - dealing with the causes, not the symptoms, Industrial and Commercial Training, 29(2), 35-40.

Rinehart \& Winston (1970). Social and psychological factors in stress McGrath, New York: Holt.

Rasch, C., Hutchison, J., \& Tollefson, N., (1986). Sources of stress among administrators at research universities. 
Selye, H. (1956). The Stress of Life, McGraw-Hill, New York, NY, in Le Fevre, M., Matheny, J., Kolt, G.

Siegrist, J. (1996). Adverse health effects of high effort-low reward conditions', Journal of Occupational Health Psychology, 1(1), 27-41.

Sharpley, C. F., Reynolds, R, Acosta, A, Dua, J. K. (1996). The presence, nature and effects of job stress on physical and psychological health at a large Australian university, Journal of Educational Administration, 34(4): 73-86

Singh, P. (2007). Effect of Stress on Job Satisfaction and Work-Values Among Teachers, Allahabad, Adhyayan Publisher distributors.

Stein, M. \& Hollowitz, J. (1992). Psyche at Work: Workplace Applications of the Jungian Analytical Psychology. Wilmette, IL: Chiron

Takahashi, A M (2014). Job- related stress in academia: The role of relative deprivation, hours' workload for different tasks and children, graduate aschool of economics, Kob University.

Thorsen, E.J. (1985). Evidences of stress in the professoriate: Task preference and health behavior, The Professoriate - Occupation in Crisis. Toronto: Higher Education Group, Ontario Institute for Studies in Education.

Tuten, T. L., \& Neidermeyer, P. E. (2004). Performance, satisfaction and turnover in call centers. The effects of stress and optimism', Journal of Business Research, 57, 2634.

Wiley. C. (2000). A synthesis of research on the causes, effects, and reduction of strategies of teacher stress. Journal of Instructional Psychology, 27(2).

Woolley, F. J. (1983). Occupational stress among community college administrators, Unpublished doctoral dissertation, University of Toronto. Toronto.

\begin{tabular}{l|l}
\hline 28 & July-December 2014
\end{tabular}

Volume 12

Number 2

JISR-MSSE 